\title{
INTERVENSI TARIF PAJAK DAERAH MENURUT UNDANG-UNDANG CIPTA KERJA: ANALISIS IMPLIKASI DAN STRATEGI PEMULIHAN EKONOMI KALA PANDEMI COVID-19
}

\author{
Arifin Nur Anggi Rahman ${ }^{1)}$; Ayodhya Agti Firdausa ${ }^{2)}$; Ma'ruf Efhaes ${ }^{3)}$ \\ ${ }^{1,2,3)}$ arifinnuranggirahman@gmail.com, Politeknik Keuangan Negara STAN
}

\begin{abstract}
This study aims to identify the importance of central government intervention in regional taxation policies and analyze the implications of these interventions for local government administration and their role in efforts to recover the economy affected by the Covid-19 pandemic. The research method used is a qualitative method. The author collects data through library research on various literatures, reports, conference results, articles, and various other types of writing that contain scientific value as a data source. The author has also reviewed and collected information and data from positive laws related to regional taxation. This study concludes that intervention in regional taxation policies is carried out to create a conducive investment climate and business activity as well as to encourage equitable distribution of economic development. Meanwhile, the intervention in regional taxation policies is able to play a role in efforts to recover the national economy, but has implications for decreasing PAD. To anticipate this turmoil, the central government can provide compensation through a balancing fund and cooperate with local governments to develop industrial agglomeration areas.

Keywords: Fiscal decentralization, intervention in local tax rates, local revenue
\end{abstract}

\begin{abstract}
Abstrak
Penelitian ini bertujuan untuk mengidentifikasi pentingnya intervensi pemerintah pusat terhadap kebijakan perpajakan daerah serta menganalisis implikasi atas intervensi tersebut bagi penyelenggaraan pemerintahan daerah serta perannya dalam upaya pemulihan perekonomian yang terdampak pandemi Covid-19. Metode penelitian yang digunakan adalah metode kualitatif. Penulis melakukan pengumpulan data melalui penelitian kepustakaan terhadap berbagai literatur, laporan, hasil konferensi, artikel, dan berbagai jenis tulisan lainnya yang mengandung nilai ilmiah sebagai sumber data. Penulis juga telah mengkaji dan menghimpun informasi dan data dari hukum positif terkait perpajakan daerah. Penelitian ini menyimpulkan bahwa intervensi terhadap kebijakan perpajakan daerah dilakukan untuk menciptakan iklim investasi dan aktivitas usaha yang kondusif serta mendorong pemerataan pembangunan ekonomi. Sementara itu, adanya intervensi terhadap kebijakan perpajakan daerah mampu berperan dalam upaya pemulihan ekonomi nasional, tetapi berimplikasi terhadap penurunan PAD. Untuk mengantisipasi gejolak tersebut, pemerintah pusat dapat memberikan kompensasi melalui dana perimbangan serta bekerja sama dengan pemerintah daerah untuk mengembangkan daerah aglomerasi industri.
\end{abstract}

Kata kunci: Desentralisasi fiskal, intervensi tarif pajak daerah, pendapatan asli daerah

\section{PENDAHULUAN}

Pada situasi pandemi seperti saat ini, pemerintah menggulirkan berbagai kebijakan untuk mengatasi kondisi yang semakin memburuk, termasuk dalam hal perekonomian Indonesia yang perlahan bangkit dari keadaan resesi yang dialami setahun belakangan ini. Sebagai contoh, pemerintah menetapkan paket kebijakan insentif pajak yang tertuang dalam Peraturan Menteri Keuangan Nomor PMK-86/PMK.03/2020 tentang Insentif Pajak Untuk Wajib Pajak Terdampak Pandemi Corona Virus Disease 2019. Upaya tersebut dilakukan untuk menjaga stabilitas dan pertumbuhan ekonomi di Indonesia. Berdasarkan data dari Badan Pusat Statistik, pada kuartal pertama tahun 2021, ekonomi Indonesia berada pada level $-0,74 \%$. Meskipun masih dalam kondisi minus, hal tersebut setidaknya lebih baik jika dibandingkan dengan kondisi pada tahun 2020 lalu.

Selain memberikan insentif pajak untuk melindungi pelaku usaha, pemerintah juga berupaya menciptakan iklim usaha yang kondusif untuk menumbuhkan investasi dalam jangka panjang. Berputarnya aktivitas usaha diharapkan mampu menyediakan lapangan pekerjaan bagi tenaga kerja yang terdampak pandemi Corona Virus Disease 2019 (Covid-19). Menteri 


\section{EDUCORETAX}

Volume 2 No. 1, 2022

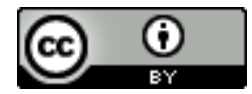

Ketenagakerjaan, Ida Fauzia, menyampaikan bahwa angka pengangguran yang diakibatkan oleh pandemi ini meningkat dari 4,9\% menjadi 7\% (Zamani, 2021). Lebih rinci, data dari Badan Pusat Statistik menjelaskan bahwa per Agustus 2020 jumlah pengangguran meningkat sebanyak 2,67 juta orang (Fauzia, 2021) Dengan adanya lapangan pekerjaan yang dapat mengurangi jumlah pengangguran, maka kondisi perekonomian masyarakat akan membaik karena masyarakat akan kembali memiliki daya beli yang sempat hilang sebesar Rp362 triliun hanya dalam waktu 10 minggu pada awal pandemi (Kontan.co.id, 2021).

Masih rendahnya minat investasi di Indonesia salah satunya disebabkan oleh disharmoni antara regulasi yang ditetapkan oleh pemerintah pusat dengan pemerintah daerah selaku pengelola daerah otonom lokasi investasi. Perizinan yang berbelit-belit, tumpang tindih kewenangan antara pemerintah pusat dengan pemerintah daerah, serta besarnya beban pajak daerah dapat menghambat investor untuk mengalirkan modalnya pada suatu daerah. Maka dari itu, pemerintah melalui Undang-undang (UU) Nomor 11 Tahun 2020 tentang Cipta Kerja menyisipkan sebuah kebijakan baru yang memberikan wewenang kepada pemerintah pusat untuk mengintervensi kebijakan perpajakan yang ditetapkan oleh pemerintah daerah. Kebijakan tersebut dilaksanakan dalam kerangka Proyek Strategis Nasional (PSN) yang digagas untuk mewujudkan pemerataan pembangunan di Indonesia.

Menurut Pasal 114 UU Nomor 11 Tahun 2020, salah satu penambahan ketentuan yang dilakukan terhadap UU Nomor 28 Tahun 2009 tentang Pajak Daerah dan Retribusi Daerah adalah penyisipan Pasal 156A sebagai dasar kewenangan pemerintah pusat untuk mengintervensi kebijakan perpajakan daerah. Kewenangan tersebut meliputi wewenang untuk melakukan pengubahan tarif pajak daerah dan retribusi daerah serta wewenang untuk melakukan pengawasan dan evaluasi terhadap peraturan daerah mengenai pajak dan retribusi yang menghambat ekosistem investasi dan aktivitas usaha. Namun, munculnya kewenangan dengan dalih meningkatkan iklim investasi tersebut dapat berimplikasi terhadap penurunan Pendapatan Asli Daerah (PAD) yang merupakan salah satu sumber penerimaan bagi daerah otonom. Padahal, PAD merupakan sumber penerimaan yang dapat dieksplorasi oleh daerah otonom untuk memenuhi kebutuhan penyelenggaraan pemerintahan daerah serta mengurangi ketergantungan terhadap dana perimbangan yang diberikan oleh pemerintah pusat.

Berdasarkan beberapa fakta yang dijelaskan pada paragraf-paragraf sebelumnya, penulis ingin mengidentifikasi alasan pemerintah melakukan intervensi terhadap kebijakan perpajakan daerah dalam rangka menumbuhkan iklim investasi yang kondusif. Selanjutnya, penulis ingin menganalisis bagaimana implikasi atas wewenang intervensi pemerintah pusat terhadap kebijakan perpajakan daerah tersebut bagi penyelenggaraan pemerintahan daerah. Penelitian yang dilakukan oleh Hariandja (2020) telah mengulas kaitan antara pajak daerah dengan pertumbuhan investasi sesuai perspektif UU Nomor 11 Tahun 2020. Akan tetapi, penelitian tersebut belum menjelaskan faktor yang melatarbelakangi terbitnya aturan intervensi kebijakan perpajakan daerah serta implikasi kebijakan tersebut secara komprehensif. Lebih lanjut, dalam penelitian ini akan diulas mengenai peran intervensi kebijakan perpajakan daerah sehubungan upaya pemulihan ekonomi Indonesia yang terdampak pandemi Covid-19.

Tujuan yang ingin dicapai antara lain: (1) Mengidentifikasi dan menguraikan alasan pemerintah melakukan intervensi terhadap kebijakan pajak daerah dan retribusi daerah; (2) Menganalisis implikasi atas intervensi pemerintah pusat terhadap kebijakan pajak daerah dan retribusi daerah bagi penyelenggaraan pemerintahan daerah serta perannya dalam upaya pemulihan ekonomi yang terdampak pandemi Covid-19

\section{KAJIAN PUSTAKA}




\section{EDUCORETAX}

Volume 2 No. 1, 2022

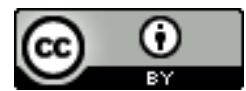

\section{Otonomi Daerah dan Desentralisasi Fiskal}

Otonomi daerah adalah suatu keadaan yang memberikan kesempatan kepada daerah untuk dapat mengoptimalkan seluruh potensi terbaik yang dimilikinya (Safitri, 2016). Pelaksanaan otonomi daerah diatur dalam Undang-undang Nomor 23 Tahun 2014 tentang Pemerintahan Daerah sebagaimana diubah terakhir dengan Undang-undang Nomor 9 Tahun 2015 tentang Perubahan Kedua atas Undang-undang Nomor 23 Tahun 2014 tentang Pemerintahan Daerah. Dalam otonomi daerah terjadi desentralisasi kewenangan kepada daerah secara utuh, salah satunya berbentuk desentralisasi fiskal.

Desentralisasi fiskal merupakan konsekuensi dari keputusan politik otonomi daerah yang diambil pemerintah. Desentralisasi fiskal diharapkan dapat menciptakan pemerataan kemampuan keuangan antar daerah yang sepadan dengan besarnya kewenangan urusan pemerintahan yang diserahkan kepada daerah otonom (Sun'an dan Senuk, 2017 dalam Christia \& Ispriyarso, 2019). Desentralisasi fiskal dapat dilakukan dari sisi pengeluaran maupun penerimaan. Desentralisasi fiskal sisi penerimaan memberikan kewenangan kepada pemerintah daerah untuk mengelola sumber pendapatan daerahnya sendiri. Sementara desentralisasi fiskal sisi pengeluaran memberikan kewenangan penuh kepada pemerintah daerah untuk mengelola pengeluaran daerahnya sendiri (Mahia \& Supriyanti, 2019).

Dalam pelaksanaannya, dampak positif dari desentralisasi fiskal adalah terbukanya kesempatan bagi pemerintah daerah untuk memanfaatkan potensi ekonomi daerahnya dalam menyelesaikan berbagai permasalahan yang ada di daerahnya. Selain itu juga mengurangi ketergantungan fiskal terhadap pemerintah pusat seiring berjalannya waktu. Namun di sisi lain, pelaksanaan desentralisasi fiskal juga menimbulkan dampak negatif seperti ketidakselarasan antara tujuan kebijakan fiskal pusat dan daerah serta meningkatnya potensi terjadinya korupsi di pemerintahan daerah.

\section{Sumber Pendapatan Daerah}

Sumber dana untuk pembangunan daerah berasal dari pendapatan asli daerah (PAD) (desentralisasi fiskal sisi penerimaan), dana perimbangan (desentralisasi fiskal sisi pengeluaran), dan lain - lain yang sah. PAD merupakan akumulasi dari penerimaan pajak yang terdiri atas pajak daerah dan retribusi daerah, penerimaan non pajak berupa penerimaan hasil perusahaan milik daerah, serta penerimaan investasi dan pengelolaan sumber daya alam (Bastian, 2002 dalam Nasir, 2019). Jumlah PAD seharusnya semakin meningkat seiring dengan bertambahnya pelimpahan kewenangan pada pemerintah daerah. Oleh karena itu, pemerintah daerah dituntut untuk mampu lebih kreatif dan inovatif dalam menggali potensi sumber PAD secara maksimal walaupun jumlah dana perimbangan dari pemerintah pusat ke pemerintah daerah sudah cukup memadai (Nasir, 2019).

Jumlah PAD merupakan tolak ukur kemandirian suatu daerah. Proporsi PAD terhadap total penerimaan daerah merupakan indikasi derajat kemandirian keuangan suatu pemerintah daerah yang disebut juga derajat otonomi fiskal (DOF) (Oktaviana, 2012). Berdasarkan penelitian yang dilakukan Nasir pada 2019, kontribusi sumber PAD kabupaten atau kota seluruh Indonesia pada tahun anggaran 2007-2013 didominasi oleh penerimaan yang bersumber dari pajak daerah. Sementara pertumbuhan sumber PAD dari tahun 2007-2013 berfluktuatif sesuai dengan kondisi dan potensi daerah masing-masing. Oleh karena itu, pajak daerah memiliki peranan yang penting sebagai sumber pendanaan di setiap daerah.

\section{Intervensi Kebijakan Pajak Daerah dan Retribusi Daerah}

Pada pasal 114 UU Nomor 11 Tahun 2020 tentang Cipta Kerja, terdapat beberapa perubahan yang dilakukan terhadap UU Nomor 28 Tahun 2009 tentang Pajak Daerah dan Retribusi Daerah. Salah satu perubahan yang dilakukan adalah penyisipan Pasal 156A di antara Pasal 156 dan Pasal 157 UU Nomor 28 Tahun 2009. Dalam pasal baru tersebut, pemerintah pusat diberi kewenangan untuk melakukan penyesuaian terhadap kebijakan pajak dan retribusi 
yang ditetapkan oleh pemerintah daerah. Dengan adanya kewenangan tersebut, pemerintah pusat dapat mengubah tarif pajak daerah dan tarif retribusi daerah dengan penetapan tarif yang berlaku secara nasional serta melakukan pengawasan dan evaluasi terhadap peraturan daerah tentang pajak daerah dan retribusi daerah. Aturan ini ditetapkan untuk mendukung kebijakan kemudahan berinvestasi serta mendorong pertumbuhan aktivitas usaha dalam rangka penyelarasan kebijakan fiskal nasional.

\section{Hubungan Keputusan Investasi dengan Peraturan Perpajakan}

Para investor biasanya melakukan dua tahapan dalam menentukan lokasi penanaman modal. Tahap pertama adalah memilih negara yang didasarkan pada besarnya pasar, akses ke bahan baku, ketersediaan tenaga kerja, dan sebagainya. Setelah memenuhi semua kriteria di tahap pertama, maka tahap keduanya adalah mengevaluasi tarif pajak, jaminan-jaminan, dan berbagai insentif yang akan didapatkan. Banyak negara berkembang menggunakan insentif pajak untuk menarik investasi modal dari dalam dan luar negeri. Insentif pajak yang sering ditawarkan adalah pajak penghasilan (Putri, 2017). Kemudian, hasil penelitian Putri (2017) menyatakan bahwa pajak atas keuntungan atau laba perusahaan dapat mempengaruhi investasi meskipun cenderung tidak signifikan. Hal ini dikarenakan terdapat faktor-faktor lain yang menjadi pertimbangan investor dalam pengambilan keputusan investasi, seperti kemudahan perizinan, besarnya pasar domestik, akses pasar internasional, Infrastruktur, kondisi sosial dan keamanan, serta ketersediaan sumber daya manusia. Titik stabilitas kelembagaan, kredibilitas dan transparansi merupakan kriteria yang difokuskan oleh investor sebelum insentif pajak. Dengan demikian, hubungan antara insentif pajak dan investasi tidak begitu kuat.

\section{Pengaruh Investasi terhadap Perekonomian}

Penanaman modal dalam negeri (PMDN) maupun penanaman modal asing (PMA) bertujuan untuk meningkatkan pertumbuhan ekonomi nasional serta meratakan dan meningkatkan kesejahteraan nasional berkelanjutan. PMA dan PMDN adalah salah satu sumber pembiayaan yang penting bagi wilayah yang sedang berkembang. Keduanya mampu memberikan kontribusi yang cukup besar bagi pembangunan. Tetapi, PMA dianggap sebagai aliran modal yang relatif stabil dibandingkan dengan aliran modal lainnya, misalnya investasi portofolio dan utang luar negeri (Kambono \& Marpaung, 2020). Lebih lanjut, dalam penelitian Kambono dan Marpaung (2020) juga menyatakan bahwa investasi asing berpengaruh positif signifikan terhadap pertumbuhan ekonomi. Sementara investasi dalam negeri tidak berpengaruh terhadap pertumbuhan ekonomi. Namun, Bimantoro dan Adriana (2016) menyatakan bahwa investasi langsung dari luar negeri hanya memiliki keterkaitan yang erat terhadap pertumbuhan ekonomi Indonesia dalam jangka pendek. Hal ini mengindikasikan bahwa manfaat investasi langsung dari luar negeri hanya dirasakan sesaat untuk menjaga stabilitas makroekonomi. Hal ini diperlihatkan dari hubungan jangka pendek yang kuat antara nilai tukar dengan investasi langsung dari luar negeri.

\section{Incremental Capital Output Ratio}

Hubungan antara pembentukan modal dan pertumbuhan output tercermin pada indikator makroekonomi yang disebut sebagai ICOR atau incremental capital output ratio. Indikator ini menunjukkan besarnya tambahan kapital baru yang dibutuhkan untuk meningkatkan satu unit output atau nilai tambah. Menurut Atjo (2019), nilai ICOR dipengaruhi oleh suku bunga yang tinggi, lahan yang mahal, sejumlah regulasi daerah yang memberatkan, kecepatan pelayanan yang rendah, perilaku dan kemampuan tenaga kerja yang kurang mendukung, serta biaya logistik yang mahal karena lemahnya dukungan infrastruktur. Nilai ICOR yang semakin kecil mengindikasikan bahwa investasi semakin efisien. Sebaliknya, nilai ICOR yang semakin besar mengindikasikan bahwa investasi semakin tidak efisien (Susilowati, et al., 2012). Oleh karena itu, upaya memperbaiki nilai ICOR menjadi salah satu prioritas bagi pemerintah pusat dan daerah. (Atjo, 2019). 
EDUCORETAX

Volume 2 No. 1, 2022

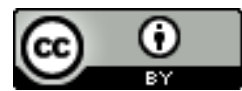

\section{Ease of Doing Business}

Ease of Doing Business (EoDB) merupakan indeks yang berkaitan dengan kemudahan berbisnis yang dibuat oleh Bank Dunia. Indeks ini menunjukkan peringkat kemudahan berbisnis di suatu negara yang didasarkan oleh beberapa indikator. EoDB telah menjadi acuan para investor dalam mengambil keputusan untuk berinvestasi di suatu negara. Indeks EoDB suatu negara yang semakin tinggi mengindikasikan peluang yang semakin besar bagi negara tersebut untuk mendapatkan investor. Dengan demikian, EoDB juga dapat dijadikan parameter bagi suatu negara dalam menentukan bagian internal yang harus dibenahi agar menarik para investor untuk berinvestasi. Berdasarkan laporan Doing Business 2020 yang dirilis oleh Bank Dunia, peringkat EoDB Indonesia adalah ke-73.

\section{METODE}

Metode penelitian yang digunakan dalam penulisan karya tulis ilmiah ini adalah metode kualitatif sehingga akan menghasilkan deskripsi berupa kata-kata tertulis. Sementara metode pengumpulan data yang akan dilaksanakan dalam pencarian data untuk melengkapi penulisan karya tulis ilmiah ini adalah sebagai berikut.

Metode penelitian kepustakaan adalah metode yang digunakan untuk penelitian yang dilakukan hanya berdasarkan atas pengkajian secara mendalam terhadap tema yang diteliti yang bersumber dari karya tertulis termasuk hasil penelitian terdahulu (Amin, 2012). Sedangkan menurut Sugiyono (2012, dikutip dalam Milya \& Asmendri, 2020), penelitian kepustakaan merupakan kajian teoritis, referensi, serta literatur ilmiah lainnya yang berkaitan dengan budaya, nilai, dan norma yang berkembang pada situasi sosial yang diteliti. Pada dasarnya, semua penulisan karya tulis ilmiah memerlukan studi kepustakaan. Namun, dalam penelitian kepustakaan, studi pustaka tidak hanya berfungsi sebagai persiapan kerangka penelitian namun juga sebagai sumber data penelitian yang akan dikaji lebih lanjut.

Pada penulisan karya tulis ilmiah ini, penulis menggunakan metode penelitian kepustakaan (library research) karena pertama, metode tersebut sudah memadai untuk menyediakan data yang diperlukan penulis sebagai dasar untuk membahas pokok permasalahan dan mencapai tujuan penulisan yang telah ditentukan sebelumnya. Kedua, adanya keterbatasan akses bagi penulis untuk berbincang langsung dengan para pihak yang terkait dengan pembuat kebijakan intervensi pajak daerah oleh pemerintah pusat. Hasil pembahasan dalam tulisan ini bersifat narasi tentang implikasi dari intervensi tarif pajak daerah yang akan dilakukan oleh pemerintah pusat.

Penulis telah menghimpun, mengkaji, dan menggunakan berbagai informasi dan data dari 25 jurnal, 9 berita dari sumber terpercaya, 5 peraturan hukum positif Indonesia yang terkait dengan materi pembahasan, data dari Badan Pusat Statistik, serta berbagai jenis tulisan lainnya yang mengandung nilai ilmiah sebagai sumber data. Berbagai sumber data tersebut didapatkan oleh penulis dari secara luring yang diterbitkan atau ditulis oleh para ahli dari dalam negeri.

\section{HASIL DAN PEMBAHASAN}

\section{Pentingnya Intervensi Pemerintah Pusat Terhadap Penetapan Tarif Pajak Daerah}

Instrumen fiskal merupakan elemen penting dalam upaya peningkatan pertumbuhan ekonomi. Sehubungan dengan pembangunan daerah, desentralisasi fiskal berpengaruh secara langsung terhadap pertumbuhan ekonomi sehingga mampu memperbaiki tingkat kesejahteraan masyarakat (Priyono et al., 2019). Adanya otonomi daerah dalam hal perpajakan menyediakan ruang bagi pemerintah daerah untuk mengoptimalkan penerimaan pajak daerah dan retribusi daerah sebagai bagian dari pendapatan asli daerah (PAD). Meskipun demikian, keselarasan antara kebijakan fiskal nasional dengan ketentuan perpajakan daerah merupakan hal yang perlu diwujudkan demi tercapainya birokrasi yang efektif. 


\section{EDUCORETAX}

Volume 2 No. 1, 2022

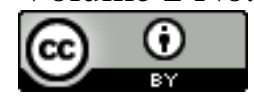

Berdasarkan Undang-undang Nomor 11 Tahun 2020 tentang Cipta Kerja, pemerintah pusat dapat melakukan intervensi terhadap kebijakan pajak daerah dan retribusi daerah dalam rangka mendukung program prioritas nasional. Pada dasarnya, intervensi dimaksudkan untuk melaksanakan kebijakan fiskal nasional, mendorong pertumbuhan industri, serta menyukseskan kebijakan kemudahan berinvestasi. Intervensi yang dilakukan pemerintah pusat dapat berupa penyesuaian tarif pajak daerah dan retribusi daerah dengan penetapan tarif yang berlaku secara nasional, pengawasan sekaligus evaluasi atas peraturan daerah yang menghambat investasi dan kemudahan berusaha, serta evaluasi rancangan peraturan daerah tentang pajak daerah dan retribusi daerah berdasarkan perspektif kebijakan fiskal nasional.

Sesuai dengan arah pembangunan wilayah sebagaimana diatur dalam Peraturan Presiden Nomor 18 Tahun 2020 tentang Rencana Pembangunan Jangka Menengah Nasional Tahun 2020-2024, pemerintah berupaya melakukan harmonisasi dan deregulasi terhadap peraturan daerah tentang pajak daerah dan retribusi daerah untuk memberikan kemudahan investasi dan berusaha. Hariandja (2020) berpendapat bahwa pemerintah telah memilih langkah yang tepat apabila ketentuan terkait intervensi desentralisasi fiskal yang diatur dalam UU Nomor 11 Tahun 2020 dicetuskan untuk menertibkan peraturan daerah yang tidak selaras dengan kebijakan fiskal nasional sehingga menyebabkan terhambatnya laju investasi. Harmonisasi kebijakan fiskal antara pusat dan daerah merupakan fokus utama yang harus diperhatikan sebelum menggagas percepatan laju investasi melalui berbagai instrumen fiskal. Dengan adanya kebijakan tersebut, investor akan mendapatkan kepastian hukum yang jelas terkait regulasi yang ditetapkan oleh pemerintah pusat dan pemerintah daerah.

Iklim investasi dan industri yang kondusif di suatu daerah dapat tercapai apabila terdapat efisiensi tarif pajak serta tidak ada pertentangan regulasi antara peraturan daerah dengan peraturan yang lebih tinggi (Adiyanta, 2018). Kedua hal tersebut mampu menghindarkan investor dari ekonomi berbiaya tinggi. Investor akan mempertimbangkan berbagai hal dalam menentukan lokasi investasinya. Selain ketersediaan infrastruktur yang menjamin jalur logistik dan proses produksi, kepastian hukum terkait perpajakan merupakan faktor penting yang harus diperhatikan untuk mendorong kegiatan investasi di daerah (Yuliadi, 2012). Pada poin inilah peran intervensi pemerintah pusat diperlukan untuk menyelidiki dan mengevaluasi faktor-faktor yang menghambat investasi pada suatu daerah, khususnya mengenai kebijakan fiskal daerah yang berlaku.

Peringkat Indonesia terkait indeks kemudahan berusaha atau dikenal dengan ease of doing business (EoDB) sebagaimana dirilis oleh World Bank mengalami perbaikan dari urutan ke-144 pada tahun 2015 menjadi urutan ke-72 pada tahun 2018. Salah satu indikator yang digunakan World Bank untuk mengukur kemudahan usaha adalah pembayaran pajak sehubungan dengan kegiatan industri dan investasi. Sementara itu, tren positif terkait investasi juga ditunjukkan dengan penurunan nilai incremental capital output ratio (ICOR) Indonesia dari 6,97 pada tahun 2015 menjadi 6,72 pada tahun 2018 sebagaimana disajikan pada Tabel 1. Peningkatan tingkat kemudahan investasi di Indonesia yang disertai penurunan nilai ICOR mengindikasikan adanya peningkatan efisiensi kegiatan investasi dalam mendorong pertumbuhan ekonomi di Indonesia sebagai respons atas pemberian kemudahan berinvestasi.

Meskipun nilai ICOR Indonesia menunjukkan tren yang positif selama periode 20152018, akan tetapi nilai ICOR Indonesia masih lebih tinggi daripada rata-rata nilai ICOR negaranegara di ASEAN selama periode 2011-2019 yang berkisar antara 3 hingga 4 (Sipahutar, 2020). Tingginya nilai ICOR Indonesia dibandingkan dengan rata-rata nilai ICOR negara-negara di kawasan ASEAN mengakibatkan Indonesia kurang dilirik oleh investor. World Bank melaporkan bahwa dari 33 perusahaan Tiongkok yang melakukan relokasi pada tahun 2019 tidak satu pun yang memilih Indonesia sebagai tujuannya (Gorbiano dan Rahman, 2019). Di kawasan ASEAN, sebanyak 23 perusahaan dari keseluruhan perusahaan tersebut memilih 


\section{EDUCORETAX}

Volume 2 No. 1, 2022

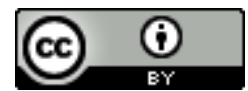

Vietnam sebagai tujuan relokasi, selebihnya tersebar di Kamboja, Malaysia, dan Thailand. Oleh karena itu, diperlukan penataan regulasi yang menghambat investasi dalam negeri maupun luar negeri untuk memperbaiki nilai ICOR Indonesia sehingga Indonesia mampu menjadi tujuan investasi yang menarik.

Tabel 1 Nilai Incremental Capital Output Ratio di Indonesia Periode 2015-2018

\begin{tabular}{|c|c|}
\hline Tahun & Nilai ICOR \\
\hline 2015 & 6,97 \\
\hline 2016 & 6,73 \\
\hline 2017 & 6,75 \\
\hline 2018 & 6,72 \\
\hline
\end{tabular}

Sumber : Badan Pusat Statistik Provinsi Daerah Istimewa Yogyakarta

Selain merumuskan strategi untuk menarik investor agar menempatkan investasinya di Indonesia, pemerintah juga dihadapkan dengan tantangan pemerataan investasi sehubungan pelaksanaan program prioritas nasional. Salah satu tujuan intervensi pemerintah pusat terhadap kebijakan perpajakan daerah adalah mewujudkan pemerataan ekonomi dalam rangka pembangunan daerah. Yuliadi (2012) dalam penelitiannya menemukan bahwa pemberian kemudahan berinvestasi dan stimulus fiskal mampu mengurangi tingkat kesenjangan investasi regional. Pasalnya, berdasarkan data realisasi investasi yang dirilis oleh Badan Koordinasi Penanaman Modal, kegiatan investasi dari luar negeri untuk periode 2012-2016 masih terpusat di wilayah Jawa. Dapat dilihat pada Tabel 2 bahwa persentase nilai realisasi investasi atas kegiatan penanaman modal asing di wilayah Jawa untuk periode 2012-2016 berkisar lebih dari $50 \%$. Fenomena ini layak menjadi fokus perhatian pemerintah untuk mengidentifikasi adakah faktor terkait fiskal yang mengakibatkan rendahnya minat investasi di wilayah selain Jawa.

Tabel 2 Persentase Nilai Realisasi Investasi Penanaman Modal Asing di Indonesia Tahun 2012-2016 Menurut Wilayah

\begin{tabular}{|l|c|c|c|c|c|}
\hline \multirow{2}{*}{ Wilayah } & \multicolumn{5}{|c|}{ Tahun } \\
\cline { 2 - 6 } & $\mathbf{2 0 1 2}$ & $\mathbf{2 0 1 3}$ & $\mathbf{2 0 1 4}$ & $\mathbf{2 0 1 5}$ & $\mathbf{2 0 1 6}$ \\
\hline Sumatera & $15,18 \%$ & $11,86 \%$ & $13,48 \%$ & $12,75 \%$ & $19,56 \%$ \\
\hline Jawa & $55,61 \%$ & $60,54 \%$ & $54,11 \%$ & $52,71 \%$ & $51,00 \%$ \\
\hline Bali dan Nusa Tenggara & $4,59 \%$ & $3,11 \%$ & $3,48 \%$ & $4,32 \%$ & $3,27 \%$ \\
\hline Kalimantan & $13,06 \%$ & $9,69 \%$ & $16,38 \%$ & $19,96 \%$ & $8,94 \%$ \\
\hline Sulawesi & $6,13 \%$ & $5,24 \%$ & $7,20 \%$ & $5,33 \%$ & $9,55 \%$ \\
\hline Maluku & $0,40 \%$ & $1,12 \%$ & $0,39 \%$ & $0,98 \%$ & $1,87 \%$ \\
\hline Papua & $5,03 \%$ & $8,44 \%$ & $4,96 \%$ & $3,95 \%$ & $5,81 \%$ \\
\hline Total & $100,00 \%$ & $100,00 \%$ & $100,00 \%$ & $100,00 \%$ & $100,00 \%$ \\
\hline
\end{tabular}

Sumber : Diolah Penulis dari Situs Web Badan Koordinasi Penanaman Modal

United Nation Conference on Trade and Development (UNCTAD) mengklasifikasikan tiga faktor ekonomi yang memengaruhi penanaman modal asing meliputi pangsa pasar, sumber daya ekonomi, dan biaya transportasi (Suparyati, 2019). Menurut Ekonom Institute for Development of Economics and Finance (INDEF), Ahmad Heri (2020 dalam Fajar, 2020), kegiatan investasi yang terpusat di wilayah Jawa terjadi karena kebanyakan investor cenderung memilih lokasi usaha yang lebih dekat dengan pasar konsumen daripada letak sumber bahan baku. Berdasarkan hasil sensus penduduk yang dilakukan oleh Badan Pusat Statistik (2021), sebanyak 151,59 juta penduduk atau 56,10 persen penduduk Indonesia memang terkonsentrasi di Pulau Jawa yang luas geografisnya hanya sekitar tujuh persen dari seluruh wilayah Indonesia. 


\section{EDUCORETAX}

Volume 2 No. 1, 2022

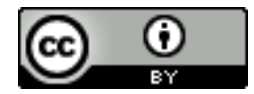

Sementara itu, daerah-daerah di luar Jawa masih menyimpan berbagai sumber daya ekonomi yang dapat dikembangkan.

Dengan adanya intervensi kebijakan fiskal, pemerintah dapat menciptakan stimulus yang mengarahkan investor untuk mengeksplorasi sumber daya ekonomi yang tersedia di wilayah selain Jawa. Sumber daya ekonomi sehubungan dengan investasi dapat meliputi ketersediaan sumber daya alam dan tenaga kerja. Potensi sumber daya ekonomi yang dimiliki oleh suatu daerah akan memberikan nilai tambah bagi daerah tersebut apabila dikembangkan dengan baik. Upaya pemerataan tersebut dipandang krusial ketika terdapat fakta bahwa sebagian besar kegiatan penanaman modal dalam negeri juga dominan berlokasi di wilayah Jawa. Tercatat selama periode 2012-2016 nilai realisasi investasi di wilayah Jawa atas kegiatan penanaman modal dalam negeri selalu lebih dari 50\% sebagaimana ditunjukkan pada Tabel 3.

Tabel 3 Persentase Nilai Realisasi Investasi Penanaman Modal Dalam Negeri di Indonesia Tahun 2012-2016 Menurut Lokasi

\begin{tabular}{|l|c|c|c|c|c|}
\hline \multirow{2}{*}{ Wilayah } & \multicolumn{5}{|c|}{ Tahun } \\
\cline { 2 - 6 } & $\mathbf{2 0 1 2}$ & $\mathbf{2 0 1 3}$ & $\mathbf{2 0 1 4}$ & $\mathbf{2 0 1 5}$ & $\mathbf{2 0 1 6}$ \\
\hline Sumatera & $15,47 \%$ & $17,88 \%$ & $18,93 \%$ & $21,04 \%$ & $18,41 \%$ \\
\hline Jawa & $57,16 \%$ & $51,89 \%$ & $62,17 \%$ & $57,81 \%$ & $58,42 \%$ \\
\hline Bali dan Nusa Tenggara & $3,44 \%$ & $3,43 \%$ & $0,30 \%$ & $1,61 \%$ & $1,22 \%$ \\
\hline Kalimantan & $18,16 \%$ & $22,41 \%$ & $13,72 \%$ & $11,15 \%$ & $15,56 \%$ \\
\hline Sulawesi & $5,32 \%$ & $2,83 \%$ & $4,56 \%$ & $7,61 \%$ & $6,27 \%$ \\
\hline Maluku & $0,35 \%$ & $0,87 \%$ & $0,10 \%$ & $0,03 \%$ & $0,01 \%$ \\
\hline Papua & $0,10 \%$ & $0,69 \%$ & $0,22 \%$ & $0,75 \%$ & $0,11 \%$ \\
\hline Total & $100,00 \%$ & $100,00 \%$ & $100,00 \%$ & $100,00 \%$ & $100,00 \%$ \\
\hline
\end{tabular}

Sumber : Diolah Penulis dari Situs Web Badan Koordinasi Penanaman Modal

Dalam pelaksanaan otonomi daerah, tidak terdapat mekanisme pengawasan preventif terhadap kebijakan pemerintah daerah untuk memberikan keleluasaan kepada daerah otonom dalam pengambilan keputusan (Isrok, 2009). Akan tetapi hal tersebut dapat mengakibatkan masalah ketika pemerintah daerah terindikasi melampaui wewenangnya. Sebagai gantinya, bentuk pengawasan represif yang terdapat pada UU Nomor 28 Tahun 2009 memberikan ruang bagi pemerintah pusat untuk menolak rancangan peraturan daerah atau membatalkan peraturan daerah terkait pajak daerah dan retribusi daerah apabila kebijakan tersebut bertentangan dengan kepentingan umum atau peraturan perundang-undangan yang lebih tinggi. Sri Mulyani (2009, dalam Isrok, 2009) menjelaskan bahwa berdasarkan hasil evaluasi terhadap peraturan daerah mengenai pajak daerah dan retribusi daerah sejak tahun 2001 hingga 2009, ditemukan 3.455 peraturan daerah dari 9.714 peraturan daerah perlu dibatalkan atau direvisi karena menghambat kegiatan investasi. Hal ini mengisyaratkan pentingnya intervensi pemerintah pusat terhadap kebijakan perpajakan daerah demi menjaga iklim investasi yang kondusif.

Kegiatan investasi yang kurang optimal mengindikasikan bahwa masih terdapat faktor yang menghambat investasi. Sebagai upaya penataan instrumen fiskal, perluasan wewenang intervensi pemerintah pusat terhadap kebijakan perpajakan daerah dalam hal penentuan tarif pajak daerah diharapkan mampu meredam ego pemerintah daerah yang menghambat kegiatan investasi. Pemerintah mengharapkan intervensi kebijakan perpajakan daerah mampu menarik minat investor dan mewujudkan pemerataan lokasi investasi di wilayah Indonesia. Pertumbuhan ekonomi daerah akan terdongkrak dengan adanya kegiatan investasi yang menghidupkan sektor-sektor perekonomian daerah. Terlebih, pemerintah juga menghadapi tantangan pemulihan perekonomian yang terdampak pandemi Covid-19. 


\section{EDUCORETAX}

Volume 2 No. 1, 2022

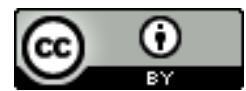

\section{Implikasi Atas Intervensi Pemerintah Pusat Terhadap Penetapan Tarif Pajak Daerah}

Penyesuaian tarif pajak daerah dan retribusi daerah dapat berpengaruh langsung terhadap pendapatan asli daerah (PAD). Usman (2017) dalam penelitiannya menyimpulkan bahwa pajak daerah berpengaruh signifikan terhadap PAD, sedangkan retribusi daerah tidak berpengaruh signifikan terhadap PAD. Direktorat Jenderal Perimbangan Keuangan (DJPK) Kementerian Keuangan menyatakan bahwa kenaikan PAD pada tahun 2018 secara nasional didorong oleh kenaikan pajak daerah. Menilik data PAD yang dirilis oleh DJPK, penerimaan pajak daerah berkontribusi lebih dari separuh PAD pada sepuluh kabupaten/ kota dengan PAD tertinggi untuk tahun 2018 sebagaimana ditunjukkan dalam Tabel 4.

Tabel 4 Kontribusi Penerimaan Pajak Daerah Terhadap PAD Pada Sepuluh Daerah dengan PAD Tertinggi Tahun 2018

\begin{tabular}{|l|c|c|c|}
\hline \multicolumn{1}{|c|}{ Daerah } & $\begin{array}{c}\text { Pendapatan Asli } \\
\text { Daerah } \\
(\mathbf{R p})\end{array}$ & $\begin{array}{c}\text { Penerimaan } \\
\text { Pajak Daerah } \\
(\mathbf{R p})\end{array}$ & $\begin{array}{c}\text { Kontribusi Penerimaan } \\
\text { Pajak Daerah terhadap } \\
\text { Pendapatan Asli Daerah } \\
(\mathbf{c}) \text { (b) }\end{array}$ \\
\hline \multicolumn{1}{|c|}{$(a)$} & $(b)$ & $(c)$ & $(d)$ \\
\hline Kota Surabaya & 4.972 .890 .868 .137 & 3.817 .402 .592 .324 & $76,76 \%$ \\
\hline Kabupaten Badung & 4.555 .716 .407 .353 & 3.872 .911 .783 .138 & $85,01 \%$ \\
\hline $\begin{array}{l}\text { Kabupaten } \\
\text { Tangerang }\end{array}$ & 2.872 .568 .512 .687 & 1.915 .261 .073 .035 & $66,67 \%$ \\
\hline Kabupaten Bogor & 2.794 .660 .740 .152 & 1.969 .519 .761 .542 & $70,47 \%$ \\
\hline Kota Bandung & 2.571 .591 .786 .199 & 2.160 .150 .277 .316 & $84,00 \%$ \\
\hline Kabupaten Bekasi & 2.094 .369 .342 .687 & 1.656 .040 .118 .350 & $79,07 \%$ \\
\hline Kota Bekasi & 2.001 .150 .459 .494 & 1.580 .754 .200 .591 & $78,99 \%$ \\
\hline Kota Tangerang & 1.864 .385 .584 .947 & 1.551 .439 .325 .839 & $83,21 \%$ \\
\hline Kota Semarang & 1.821 .274 .103 .250 & 1.331 .817 .746 .450 & $73,13 \%$ \\
\hline Kabupaten Sidoarjo & 1.685 .558 .666 .148 & 961.840 .717 .557 & $57,06 \%$ \\
\hline
\end{tabular}

Sumber : Portal Data DJPK

Dari sepuluh daerah yang tercantum pada Tabel 4, lima daerah dengan kontribusi penerimaan pajak daerah terhadap PAD tertinggi, yaitu Kabupaten Badung, Kota Bandung, Kota Tangerang, Kabupaten Bekasi, dan Kota Bekasi umumnya menetapkan tarif tertinggi sesuai dengan UU Nomor 28 Tahun 2009 untuk beberapa jenis pajak daerah yang menjadi wewenang pengelolaannya sebagaimana ditunjukkan pada Tabel 5. Kelima daerah tersebut menetapkan tarif tertinggi untuk lima jenis pajak daerah yang dikelola kabupaten/ kota meliputi Pajak Hotel, Pajak Restoran, Pajak Reklame, Pajak Air Tanah, dan Bea Perolehan Hak atas Tanah dan Bangunan (BPHTB). Sementara itu, tarif Pajak Mineral Bukan Logam yang dikelola oleh Kabupaten Badung dan Kabupaten Bekasi juga berada pada angka tertinggi sesuai dengan UU Nomor 28 Tahun 2009. Penetapan tarif tertinggi tersebut dapat diindikasi sebagai upaya optimalisasi penerimaan pajak daerah dalam rangka perolehan pendapatan asli daerah. 


\section{EDUCORETAX}

Volume 2 No. 1, 2022



Tabel 5 Tarif Pajak Daerah Pada Lima Daerah Dengan Kontribusi Pajak Daerah Terhadap PAD Tertinggi Tahun 2018

\begin{tabular}{|c|c|c|c|c|c|c|c|c|}
\hline \multirow[b]{2}{*}{ Daerah } & \multicolumn{8}{|c|}{ Tarif Pajak Daerah } \\
\hline & 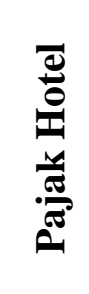 & 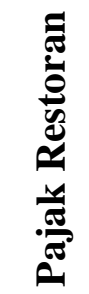 & 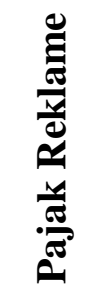 & 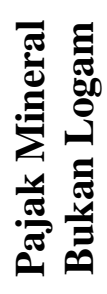 & 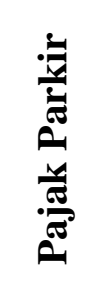 & 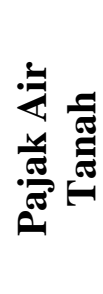 & 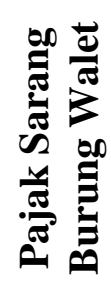 & 党 \\
\hline Kabupaten Badung & $10 \%$ & $10 \%$ & $25 \%$ & $25 \%$ & $25 \%$ & $20 \%$ & - & $5 \%$ \\
\hline Kota Bandung & $10 \%$ & $10 \%$ & $25 \%$ & - & $25 \%$ & $20 \%$ & - & $5 \%$ \\
\hline Kota Tangerang & $10 \%$ & $10 \%$ & $25 \%$ & - & $25 \%$ & $20 \%$ & - & $5 \%$ \\
\hline Kabupaten Bekasi & $10 \%$ & $10 \%$ & $25 \%$ & $25 \%$ & $25 \%$ & $20 \%$ & $10 \%$ & $5 \%$ \\
\hline Kota Bekasi & $10 \%$ & $10 \%$ & $25 \%$ & - & $30 \%$ & $20 \%$ & - & $5 \%$ \\
\hline $\begin{array}{l}\text { Tarif tertinggi sesuai } \\
\text { UU Nomor } 28 \\
\text { Tahun } 2009\end{array}$ & $10 \%$ & $10 \%$ & $25 \%$ & $25 \%$ & $30 \%$ & $20 \%$ & $10 \%$ & $5 \%$ \\
\hline
\end{tabular}

Sumber : Diolah Penulis dari Peraturan Daerah tentang Pajak Daerah dan Retribusi Daerah untuk setiap daerah terkait

Apabila intervensi kebijakan perpajakan daerah dilakukan oleh pemerintah pusat dengan menurunkan tarif pajak daerah yang semula ditetapkan pada batas tertinggi sesuai UU Nomor 28 Tahun 2009, maka akan terjadi gejolak dalam jangka pendek berupa penurunan kontribusi penerimaan pajak daerah terhadap pendapatan asli daerah. Terlebih, penyesuaian tarif yang diberlakukan secara nasional dapat menimbulkan masalah ketika kemampuan keuangan daerah berada dalam tingkatan yang berbeda-beda. Bagi daerah dengan rasio PAD yang tinggi akan mengalami penurunan optimalisasi perolehan PAD, sedangkan daerah dengan rasio PAD yang rendah akan mengalami penurunan kemampuan keuangan daerah semakin dalam. Pemerintah daerah akan mengalami kesulitan dalam menyesuaikan penerimaan dan pengeluaran sehubungan dengan preferensi kebijakan yang dikehendaki masyarakat setempat (Tjip Ismail, 2018 dalam Alqadri, 2020).

Berkurangnya porsi penerimaan pada pendapatan asli daerah yang semula digunakan untuk mendanai operasional pemerintah daerah dapat berdampak terhadap penyelenggaraan pelayanan publik. Hariandja (2020) dalam penelitiannya memberikan catatan bahwa pendapatan asli daerah yang rendah berpotensi mengakibatkan penurunan tingkat pelayanan publik oleh pemerintah daerah kepada masyarakatnya. Tak dapat dipungkiri bahwa belanja modal dalam rangka penyelenggaraan publik oleh pemerintah daerah memerlukan dana yang cukup besar sehingga dibutuhkan dukungan kinerja keuangan daerah yang baik (Riswan \& Affandi, 2014).

Anggara dan Cheisviyanny (2020) dalam penelitiannya menyimpulkan bahwa tingkat penerimaan pendapatan asli daerah yang rendah menyebabkan pemerintah daerah memiliki ketergantungan terhadap dana perimbangan dari pemerintah pusat. Meskipun demikian, salah satu opsi yang dapat dipilih oleh pemerintah pusat sebagai kompensasi atas penurunan pendapatan asli daerah akibat penyesuaian tarif pajak daerah adalah penambahan dana perimbangan sehingga intervensi tersebut tidak mengganggu postur anggaran pendapatan dan belanja daerah. Transfer dana dari pusat ke daerah berperan untuk menjamin penyediaan pelayanan tertentu yang belum dapat dicukupi oleh pemerintah daerah sekaligus mewujudkan pemerataan potensi pajak di antara sesama pemerintah daerah (Yuliadi, 2012). 


\section{EDUCORETAX}

Volume 2 No. 1, 2022

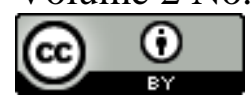

Dana perimbangan yang diberikan secara cermat dan terukur diharapkan mampu menjadi dukungan keuangan bagi pemerintah daerah dalam penyelenggaraan pelayanan kepada masyarakat (Arbani, 2020). Berdasarkan ringkasan anggaran pendapatan dan belanja daerah tahun 2018 yang disusun oleh DJPK, rata-rata rasio dana perimbangan terhadap pendapatan daerah untuk setiap provinsi adalah 57,9\%, sedangkan rata-rata rasio PAD terhadap pendapatan daerah untuk setiap provinsi sebesar 35,2\%. Pada Tabel 6 ditunjukkan bahwa tiga daerah dengan rasio PAD terhadap pendapatan daerah tertinggi untuk tahun 2018 meliputi DKI Jakarta, Banten, dan Kalimantan Selatan relatif memiliki rasio dana perimbangan terhadap pendapatan daerah yang lebih kecil dari rata-rata nasional. Sementara itu, tiga dengan rasio dana perimbangan terhadap pendapatan daerah tertinggi untuk tahun 2018 meliputi Maluku Utara, Sulawesi Tenggara, dan Sulawesi Barat relatif memiliki rasio PAD terhadap pendapatan daerah yang lebih kecil dari rata-rata nasional. Hal tersebut dapat menunjukkan kedudukan dana perimbangan sebagai komplemen atas tingkat pencapaian pendapatan asli daerah.

Tabel 6 Perbandingan Rasio PAD terhadap Pendapatan Daerah dengan Rasio Dana Perimbangan terhadap Pendapatan Daerah Tahun 2018

\begin{tabular}{|l|c|c|}
\hline \multicolumn{1}{|c|}{ Daerah } & $\begin{array}{c}\text { Rasio PAD terhadap } \\
\text { Pendapatan Daerah }\end{array}$ & $\begin{array}{c}\text { Rasio Dana } \\
\text { Perimbangan terhadap } \\
\text { Pendapatan Daerah }\end{array}$ \\
\hline DKI Jakarta & $67,5 \%$ & $32,4 \%$ \\
\hline Banten & $59,7 \%$ & $40,3 \%$ \\
\hline Kalimantan Selatan & $57,4 \%$ & $41,9 \%$ \\
\hline Rata-rata nasional & $35,2 \%$ & $57,9 \%$ \\
\hline Maluku Utara & $10,6 \%$ & $84,5 \%$ \\
\hline Sulawesi Tenggara & $17,6 \%$ & $81,9 \%$ \\
\hline Sulawesi Barat & $17,9 \%$ & $81,1 \%$ \\
\hline
\end{tabular}

Sumber : Direktorat Jenderal Perimbangan Keuangan

Meskipun intervensi kebijakan perpajakan daerah dalam jangka pendek dapat berimplikasi negatif terhadap kemampuan keuangan daerah, akan tetapi pertumbuhan kegiatan investasi di daerah dalam jangka panjang akan memperluas potensi pemajakan sehingga tercapai penerimaan pajak daerah yang optimal. Secara simultan pendapatan asli daerah akan terdongkrak seiring pertumbuhan ekonomi sebagai dampak kegiatan investasi dan industri yang berlangsung di daerah. Pertumbuhan ekonomi yang semakin meningkat dapat menambah daya tarik investasi sehingga pembangunan daerah dapat berjalan secara maksimal (Arini dan Kusuma, 2019). Bahkan, tingkat penyerapan tenaga kerja juga akan meningkat apabila pemerintah mampu meningkatkan kualitas sumber daya manusia dalam rangka mendukung produktivitas kegiatan perekonomian daerah. Sesuai teori pertumbuhan neoklasik, salah satu faktor yang mempengaruhi pertumbuhan output adalah kenaikan kualitas tenaga kerja melalui upaya perbaikan pendidikan (Nizar et al., 2013).

Kondisi pandemi Covid-19 yang mengancam perekonomian negara menuntut pemerintah untuk merumuskan langkah strategis dan luar biasa di bidang keuangan negara. Melalui UU Nomor 2 Tahun 2020, berbagai kebijakan ditetapkan dalam rangka menyelamatkan perekonomian nasional dan menjaga stabilitas keuangan negara. Berkaitan dengan hal tersebut, dicetuskannya wewenang intervensi pemerintah pusat terhadap tarif pajak daerah sesuai UU Nomor 11 Tahun 2020 dapat menjadi salah satu opsi instrumen fiskal yang mendukung pemulihan ekonomi nasional secara berkesinambungan. Pasalnya, stimulus fiskal yang diberikan untuk mengatasi gejolak ekonomi akibat pandemi hanyalah bersifat sementara. Padahal, dampak tekanan ekonomi akibat pandemi Covid-19 akan mempengaruhi struktur perekonomian secara jangka panjang. 


\section{EDUCORETAX}

Volume 2 No. 1, 2022

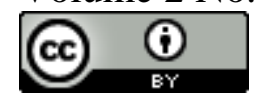

Intervensi kebijakan fiskal daerah dalam rangka upaya pemulihan ekonomi perlu mempertimbangkan potensi khas yang ada pada setiap daerah (Modjo, 2020). Lebih lanjut, pemerintah dapat mengembangkan daerah aglomerasi industri untuk meningkatkan efisiensi ekosistem usaha. Aglomerasi industri merupakan pemusatan industri pada suatu kawasan khusus untuk mengoptimalkan aktivitas industri (Febriansyah, 2020). Aktivitas usaha akan efektif apabila suatu industri memiliki penunjang kegiatan operasi di lokasi usahanya. Pengelolaan input, pemrosesan, hingga output yang terintegrasi dalam suatu wilayah diharapkan mampu menghemat biaya usaha. Dengan adanya pertumbuhan aktivitas usaha yang positif, pemerintah mampu menjaga dan meningkatkan stabilitas ekonomi.

\section{PENUTUP}

\section{Simpulan}

Kewenangan intervensi terhadap kebijakan pajak daerah dan retribusi daerah oleh pemerintah pusat yang tercantum pada Pasal 114 UU Nomor 11 Tahun 2020 digagas untuk mewujudkan keselarasan regulasi fiskal antara pemerintah pusat dengan pemerintah daerah sehingga tercipta iklim investasi dan aktivitas usaha yang kondusif di Indonesia. Hal tersebut dapat tercapai dengan adanya kepastian hukum dan efisiensi biaya terkait aspek fiskal bagi investor dan pelaku usaha. Selain itu, pemerintah berupaya menumbuhkan minat investasi di seluruh wilayah Indonesia dalam rangka mendorong pemerataan pembangunan ekonomi dengan wewenang tersebut. Penyesuaian tarif pajak daerah berpotensi mengakibatkan penurunan pendapatan asli daerah yang berdampak pada penyelenggaraan pelayanan publik oleh pemerintah daerah dalam jangka pendek. Namun, penerapan kebijakan tersebut dalam jangka panjang dapat memperluas potensi pemajakan sehingga mampu mendorong pertumbuhan ekonomi. Secara berkesinambungan, instrumen fiskal tersebut juga berperan dalam upaya pemulihan perekonomian Indonesia yang terdampak pandemi Covid-19.

\section{Saran}

Untuk mengatasi gejolak akibat penurunan pendapatan asli daerah setelah penyesuaian tarif pajak daerah, pemerintah pusat dapat memberikan kompensasi melalui dana perimbangan sehingga kegiatan pemerintahan daerah dan penyelenggaraan pelayanan publik tetap terlaksana secara efektif. Pemerintah pusat dan pemerintah daerah dapat bekerja sama untuk mengembangkan daerah aglomerasi industri demi meningkatkan efisiensi ekosistem usaha yang terintegrasi sehingga mampu mendorong pertumbuhan ekonomi secara berkesinambungan.

\section{DAFTAR PUSTAKA}

Adiyanta, F. S. (2018). Menakar Produk Regulasi Pemerintah Kabupaten/ Kota yang Kondusif bagi Investasi di Daerah. Administrative Law and Governance Journal, 1(3), 240-258.

Alqadri, M. S. (2020). Analisis RUU Omnibus Law Perpajakan Terhadap Pemungutan Pajak Daerah. Tanjungpura Law Journal, 4(2), 117-132.

Amin, A. R. (2012). Penelitian Kepustakaan (Library Research). Diambil dari Banjir Embun: https://www.banjirembun.com/2012/04/penelitian-kepustakaan.html

Anggara, E., \& Cheisviyanny, C. (2020). Pengaruh Pendapatan Asli Daerah, Ukuran Pemerintah Daerah, Tingkat Ketergantungan Pemerintah Daerah Terhadap Tingkat Pengungkapan Laporan Keuangan Pemerintah Daerah. Jurnal Eksplorasi Akuntansi, 2(1), 2162-2184.

Arbani, T. S. (2020). Kebijakan Pemerintah Terhadap Pengalokasian Dana Alokasi Umum dan Ketergantungan Pemerintah Daerah. Al-'Adl, 13(1), 94-106. 


\section{EDUCORETAX}

Volume 2 No. 1, 2022

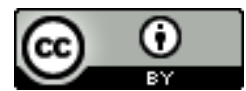

Arini, P. R., \& Kusuma, M. W. (2019). Pengaruh Belanja Modal dan Pendapatan Asli Daerah Terhadap Investasi Swasta di Indonesia dengan Pertumbuhan Ekonomi Sebagai Variabel Intervening. Jurnal Riset Akuntansi Mercu Buana, 5(1), 28-38.

Asmendri, M. S. (2020). Penelitian Kepustakaan (Library Research) dalam Penelitian Pendidikan IPA. Natural Science : Jurnal Penelitian Bidang IPA dan Pendidikan IPA, 41-53.

Atjo, H. (2019). Nilai Icor Indonesia Tinggi, Minat Investasi Rendah. Diambil dari Kumparan Website: https://kumparan.com/paluposo/nilai-icor-indonesia-tinggi-minat-investasirendah-1sMG5yxIi2g

Badan Pusat Statistik. (2021). Hasil Sensus Penduduk 2020.

Badan Pusat Statistik Provinsi Daerah Istimewa Yogyakarta. (2020). Laporan Akhir Analisis ICOR Sektoral DIY 2015-2019.

Bimantoro, F., \& Adriana, M. (2016). Pengaruh Penanaman Modal Asing terhadap Pertumbuhan Ekonomi di Indonesia. Media Ekonomi 2, 4(1).

Christia, A. M., \& Ispriyarso, B. (2019). Desentralisasi Fiskal dan Otonomi Daerah di Indonesia. Law Reform, 15(1).

Fajar, T. (2020). Investasi RI Terpusat di Pulau Jawa, Ternyata Ini Penyebabnya. Diambil dari OKEFINANCE:

https://economy.okezone.com/read/2020/10/13/320/2292885/investasi-ri-terpusat-dipulau-jawa-ternyata-ini-penyebabnya?page $=2$

Fauzia, M. (2021). Satu Tahun Pandemi: Jumlah Pengangguran Nyaris 10 Juta, Angka Kemiskinan Tembus 10 Persen. Diambil dari Kompas.com: https://money.kompas.com/read/2021/03/02/161627926/satu-tahun-pandemi-jumlahpengangguran-nyaris-10-juta-angka-kemiskinan-tembus?page $=$ all

Febriansyah, B. (2020). Pengaruh Aglomerasi Industri Terhadap Pertumbuhan Ekonomi di Provinsi Sumatera Utara. Institut Agama Islam Negeri Padangsidimpuan.

Gorbiano, M. I., \& Rahman, R. (2019, September 10). Foreign Investments Flow to Neighbors Instead of Indonesia: World Bank. Diambil dari The Jakarta Post: https://www.thejakartapost.com/news/2019/09/10/foreign-investments-flow-toneighbors-instead-of-indonesia-world-bank.html

Hariandja, F. (2020). Pajak Daerah dan Retribusi Daerah (PDRD) Dikaitkan dengan Pertumbuhan Investasi. Jurnal Suara Hukum, 2(2), 154-183.

Isrok, A. (2009). Korelasi Antara Peraturan Daerah (Perda) Bermasalah dengan Tingkat Investasi ke Daerah. Ius Quia Iustum Law Journal, 16(4), 551-568.

Kambono, H., \& Marpaung, E. I. (2020). Pengaruh Investasi Asing dan Investasi Dalam Negeri terhadap Pertumbuhan Ekonomi Indonesia. Jurnal Akuntansi, 12(1), 137-145.

Kontan.co.id. (2021). BPS catat pertumbuhan ekonomi Indonesia minus 0,74\% pada kuartal I2021. Diambil dari Kontan.co.id: https://nasional.kontan.co.id/news/bps-catatpertumbuhan-ekonomi-indonesia-minus-074-pada-kuartal-i-2021

Mahia, B. R., \& Supriyanti, S. S. (2019). Dampak Desentralisasi Fiskal terhadap Volatilitas Belanja Pemerintah Kabupaten/Kota di Indonesia. Jurnal Ekonomi dan Pembangunan Indonesia, 19(1).

Modjo, M. I. (2020). Memetakan Jalan Penguatan Ekonomi Pasca Pandemi. The Indonesian Journal of Development Planning, 4(2), 103-116.

Nasir, M. S. (2019). Analisis Sumber-Sumber Pendapatan Asli Daerah. Jurnal Dinamika Ekonomi Pembangunan, 2(1), 30-45.

Nizar, C., Hamzah, A., \& Syahnur, S. (2013). Pengaruh Investasi dan Tenaga Kerja Terhadap Pertumbuhan Ekonomi Serta Hubungannya Terhadap Tingkat Kemiskinan di Indonesia. Jurnal Ilmu Ekonomi, 1(2), 1-8. 


\section{EDUCORETAX}

Volume 2 No. 1, 2022

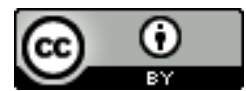

Oktaviana, D. (2012). Analisis Pendapatan Asli Daerah dan Faktor-Faktor yang Mempengaruhinya dalam Rangka Otonomi Daerah: Pendekatan Error Correction Model. Jurnal Ekonomi Pembangunan, 10(2).

Peraturan Menteri Keuangan Nomor PMK-86/PMK.03/2020 tentang Insentif Pajak untuk Wajib Pajak Terdampak Pandemi Corona Virus Disease 2019.

Peraturan Presiden Nomor 109 Tahun 2020 tentang Perubahan Ketiga Atas Peraturan Pemerintah Nomor 3 Tahun 2016 Tentang Percepatan Pelaksanaan Proyek Stategis Nasional .

Priyono, N., Juliprijanto, W., \& Setyawan, S. (2019). Studi Empiris : Peran Desentralisasi Fiskal Terhadap Peningkatan Kesejahteraaan Masyarakat dengan Pertumbuhan Ekonomi Sebagai Variabel Intervening Pada Kabupaten/ Kota di Indonesia. Jurnal RAK (Riset Akuntansi Keuangan), 4(2), 13-25.

Putri, W. A. (2017). Insentif Pajak dalam Membentuk Keputusan Investasi. Jurnal Moneter, $4(2)$.

Riswan, R., \& Affandi, A. (2014). Pengaruh Kinerja Keuangan Daerah Terhadap Belanja Modal Untuk Pelayanan Publik Dalam Perspektif Teori Keagenan. Jurnal Akuntansi Dan Keuangan, 5(2), 71-90.

Safitri, S. (2016). Sejarah Perkembangan Otonomi Daerah di Indonesia. Jurnal Criksektra, 5(9).

Setiawan, D. A. (2020). Pemerintah Pusat Dapat Intervensi Tarif Pajak Daerah, Ini Ketentuannya. Diambil dari DDTC News: https://news.ddtc.co.id/pemerintah-pusatdapat-intervensi-tarif-pajak-daerah-ini-ketentuannya-24511?page_y=0

Sipahutar, M. A. (2020). Efisiensi Investasi Tingkatkan Penyerapan Tenaga Kerja. Diambil dari INVESTOR.ID: https://investor.id/opinion/efisiensi-investasi-tingkatkanpenyerapan-tenaga-kerja

Suparyati, A. (2019). Pengaruh Kinerja Makroekonomi Terhadap Penanaman Modal Asing di Indonesia Bagian Timur dan Tengah. Media Ekonomi, 27(1), 85-94.

Susilowati, S. H., Hadi, P. U., Friyatno, S., Rachmat, M., Maulana, M., \& Azis, M. (2012). Estimasi Incremental Capital Output Ratio (ICOR) untuk Perencanaan Investasi dalam Rangka Pembangunan Sektor Pertanian. Jurnal Agro Ekonomi, 30(2), 159-182.

Undang-Undang Nomor 11 Tahun 2020 tentang Cipta Kerja.

Undang-Undang Nomor 2 Tahun 2020 tentang Penetapan Peraturan Pemerintah Pengganti Undang-Undang Nomor 1 Tahun 2020 tentang Kebijakan Keuangan Negara dan Stabilitas Sistem Keuangan Untuk Penanganan Pandemi Corona Virus Disease 2019 (Covid-19) dan/ atau Dalam Rangka Menghadapi Ancaman Yang Membahayakan Perekonomian Nasional dan/ atau Stabilitas Sistem Keuangan Menjadi Undang-Undang. Undang-Undang Nomor 28 Tahun 2009 tentang Pajak Daerah dan Retribusi Daerah.

Usman, R. (2017). Pengaruh Pajak Daerah dan Retribusi Daerah Terhadap Pendapatan Asli Daerah (PAD). JAF-Jurnal of Accounting and Finance, 1(01), 87-103.

Yuliadi, I. (2012). Kesenjangan Investasi dan Evaluasi Kebijakan Pemekaran Wilayah di Indonesia. Jurnal Ekonomi Pembangunan, 13(2), 276-287.

Zamani, L. (2021). Pandemi Covid-19, Jumlah Pengangguran di Indonesia Naik 9,7 Juta Orang. Diambil dari Kompas.com: https://regional.kompas.com/read/2021/03/10/160618878/pandemi-covid-19-jumlahpengangguran-di-indonesia-naik-97-juta-orang 